\title{
European Energy Exchange EEX - Alternative for the Development of the Bulgarian Electricity Market
}

\author{
Assoc. Prof. Dr. Todor Nedev \\ Department of Finance University of National and World Economy, Sofia, Bulgaria
}

\section{Doi:10.5901/ajis.2015.v4n1s2p259}

\begin{abstract}
The price of electricity in the Republic Bargariya was always a topic and permanent food for thought for both businesses and households as final consumers. The paper aims to show the specificity of trade in electricity - in principle and in chasnost features and imbalances on the Bulgarian market. To demonstrate the need for organized and working stock market for electricity and the need for their daily work transparent. The accession of Bulgarian electricity market to the European Energy Exchange EEX would be the best alternative for solving problems.
\end{abstract}

Keywords: Market Pricing; electric energy market, Energy Prices; European Energy Exchange - EEX

\section{Introduction}

A sector for sale of electric energy became operational in August 2000 with the Group of the German Exchange (Gruppe Deutsche Börse) in Frankfurt. The exchange is called European Energy Exchange - EEX). Transactions are made on EEX with all primary-energy sources: electric energy, natural gas, coal, oil and harmful emission quotas.

Cash power exchange market - EPEX SPOT is the cash power market uniting the markets of France, Germany, Austria and Switzerland. Together these countries represent more than a third of electricity consumption in Europe. The seat of the company is in Paris with offices in Leipzig, Bern and Vienna. It was established in 2008 based on the merger of the power exchanges Powernext SA of France and EEX AG in Germany. Gradually integrated to the market of these four countries are the markets of Italy, Spain, Czechia, Slovakia, Poland, Hungary, Greece and Romania.

The exchange mechanism allows the arrangement of offers as legally binding agreements for purchase or sale of a particular quantity of electric energy in a given zone, for supply at a determined price (the so-called market clearing price).

Completed deals are forwarded immediately to the central counterparty for each transaction - the European Commodity Clearing (ECC). It is a central counterparty for all buyers and sellers who, as a rule, do not know each other. The clearing organization will always step in as a universal intermediary between buyer and seller, i.e. it provides for both the liabilities of buyer versus seller (payment for the electric energy), and for those of seller to buyer (the delivery of electricity).

As an important result of the exchange trade EPEX SPOT publishes daily exchange prices which are determined in a direct meeting of demand and supply. As such transactions are the result of extensive, open and transparent competition between orders by members of the Exchange they reflect the best available information as at this point of time in the market environment. Usually the cash market is organized 'a day ahead' and 'within the day'.

The number of players on the EPEX SPOT cash market is continuously growing and at this point of time they are 236 firms from 24 countries, and there are licensed traders including from Romania and Greece. It is enough to look at the map with the geographical location of players in trade on the European Energy Exchange and the legitimate question will arise - why no Bulgarian participation on this market. While the exchange market guarantees:

- $\quad$ fair and adequate behaviour of members of the Exchange;

- $\quad$ safe delivery and payment for the traded electric energy;

- anonymity of transactions - producers do not know to whom they sell and buyers do not know from whom they will buy actually;

- transparency in determination and variation of the price in accordance with demand and supply for every moment of the day.

Calculated by the cash market of the EEX exchange are also the respective indexes by which graphically presented is the variation in electricity price from various sectors of the market: 
Phelix - index for physical delivery (Physical Electricity Index) - reporting on a daily basis a published price for base load (Phelix Base) ad the peak load (Phelix Peak) on the market of electric energy for the area of Germany and Austria market. The index is calculated from prices on the EPEX SPOT cash market (the exchange acronym for such market). It is calculated as unweighted arithmetic average in two variants: with base load and with peak load. The index is used as a base (underlying) asset for Phelix futures and options traded actively on the European Energy Exchange.

Daily PHELIX index for base load (Phelix Day Base) is the unweighted arithmetic average price of electric energy for the hours from 1 to 24 traded on the spot market. It is calculated for all calendar days of the year.

Daily PHELIX index with peak load (Phelix Day Peak) averages the prices of electric energy traded on the spot market for the hours from $9^{\text {th }}$ to $20^{\text {th }}$ hour for all business days of the year.

Monthly PHELIX index for base load (Phelix Month Base) is calculated as an arithmetic average of all day values of the index for all calendar days of the month.

Monthly PHELIX index with peak load (Phelix Month Peak) is calculated as the average (unweighted) of all values of the PHELIX Day for all days from Monday to Friday of the respective month.

The wholesale price of electric energy varies within wiled limits yet it is always the result of the momentary ratio of electricity demand and supply.

In line with the cash transactions also possible are three main types of term transactions - futures with physical delivery, financial futures and options. They feature a similar method of determining the price - in auction or an ongoing price fixation. Traded on the European Energy Exchange are also options, yet for the territories of Germany and Austria only. They are called PHELIX options as they are based on the PHELIX index and have a possible maturity - month, quarter, year. futures.

Futures contracts for supply of electric energy are two main types - futures with physical delivery and financial

Traded on the European Energy Exchange are futures with physical delivery of electric energy for the territories of France, Belgium and Denmark. Such futures come to an end with physical delivery of the whole quantity of electric energy for the entire period of the contract. Calculated in the last trading day (for week futures) and two exchange days before the period of delivery for the months futures is an 'ending price' for the futures. Usually this is the last price at closure of the trade in such futures. The buyer of a futures contract is obliged to receive the entire contracted quantity of electric energy for the whole period of the contract and to pay it at the ending price. The seller of the futures contract is obliged to deliver the contracted electric energy at constant parameters for each day and hour of the period of supply. Generally the contracts make provision for delivery of $1 \mathrm{MWh}$ of electricity per each astronomical hour of the period of supply.

Financial futures admitted for trading are for the territories of Germany/Austria, France and Italy:

Review will be made here only of financial futures for the territory of Germany and Austria based on the PHELIX index:

- Financial futures on the Phelix index for base load (daily, weekend, weekly, monthly, quarterly and yearly) Phelix-Base-Day/Weekend/Week/Month/Quarter/Year-Futures;

- Financial futures on the Phelix index for peak load (daily, weekend, weekly, monthly, quarterly and yearly) Phelix-Peak-Day/Weekend/Week/Month/Quarter/Year-Futures;

- Financial futures on the Phelix index without peak load (monthly, quarterly and yearly) - Phelix-Off-PeakMonth/Quarter/Year-Futures;

Starting February 2015 French and Italian futures will be released for the days and for the weekend, as well as financial futures for the territories of Spain and Switzerland.

The ending price for financial futures is determined on the calculation after a particular index which averages the prices from auctions for each hour of the day/night on the cash market 'day forward' per each discrete market territory. Usually prices are determined for base load, for peak load and for off-peak load, respectively. Ending of financial futures takes place only with equalization of the position with payment. i.e. there is no physical delivery of electric energy here. On maturity day the buyer of the financial futures is obliged to pay the difference between futures price and the fixed lower ending price. Where the ending price is higher than the futures price the difference is then paid by the seller of the futures contract. Such payment shall be effected until two days after maturity of clearing.

Options are another type of term transactions in which a right is being bought. Rights are two types: in the case of Call-option the right is 'to buy' at the price of exercise and in the case of Put-option the right is 'to sell' at exercise price. The buyer of a put option is entitled to receive a short position in a respective futures at the option exercise price on the 
last trading day. The seller of a put option receives, when exercising a long position in the respective futures, an Option Premium - this is the exchange price, which is paid at buying the right. Types of options - they are European type, which means that options are exercised on the last day for trading only. Option series - these are all call and put options on one and the same base asset with same exercise prices and one and the same maturity period. Offered for the first trading day for each maturity period are at least three series with different exercise prices - one of them shall be 'cash' (in-themoney), the second one - 'on money' (at-the-money) and the third price must be 'out of money' (out-of-the-money).

Traded maturity periods - in the case of Phelix year options there are four possible contracts with possible maturity coming in the end of each quarter of the current year:

- maturity at the end of March - April Phelix year option for base load (Phelix-Base-Year-Apr-Option);

- maturity at the end of June - July Phelix year option for base load (Phelix-Base-Year-Jul-Option);

- maturity at the end of September - October Phelix year option for base load (Phelix-Base-Year-Oct-Option);

- maturity at the end of December - January Phelix year option for base load (Phelix-Base-Year-Jan-Option).

The price of electric energy in the $\mathrm{R}$ of Bulgaria has always been a topical theme and a permanent reason for reflection for the business and the households, both of them as end consumers. The present article is intended to show the specifics of trade in electric energy - in principle and in particular the peculiarities and disproportions of Bulgarian market, these actually being an obstacle for the development of a normal competition on this market. Still observed in the Bulgarian electric energy market are multiple restrictions on participants in this trade that prove the limitation on competition when transactions are made in electric energy thus delaying actually the transformation of the market from state monopoly to an efficient market.

The legislative framework of the European Union for the electric energy market is embedded in Directive 2009/72/EC. (DIRECTIVE 2009/72/EC OF THE EUROPEAN PARLIAMENT AND THE COUNCIL of 13 June 2009 concerning the common rules for the internal market in electric energy). [ 4 ]

The main actions, terms and objectives for implementation by the member states can be summarized and presented as follows:

- $\quad$ Main purpose: to achieve a '...fully open market, which enables all consumers to freely choose their suppliers and all suppliers freely to deliver to their customers.'

- $\quad$ The full market opening aims at dividing generation from delivery of electric energy, so that conditions could be established of loyal competition and opportunities for market impact on the changes in electric energy price;

- $\quad$ The Directive requires that all producers shall be competitively put on a level playing field in an objective, transparent and non-discriminatory manner, as well as third-party access to be provided to the transmission and distribution systems in conformity with the requirements for full market opening;

- $\quad$ Electric energy production is always regionally individualized. The maximum possible generation by all producers of electric energy is defined as a maximum capacity of such territory. The electric energy market in the US, for example, is divided up into 140 regions, also having 140 control points that measure the quantities of electric energy going out of or coming into the region, this being sold, or purchased by the other region, respectively. The possibilities for sale of electric energy of another region are determined by the possibilities of energy transmission between the two regions $[9$, p. 713]

- $\quad$ The market of electric energy, like the market of other primary-energy sources, must be transformed from a state monopoly to an efficient market with the help of appropriate regulations. 'This process is always accompanied also with the establishment of a term market for derivatives on contracts for supply of electric energy.' [9, p.714]

The issues relative to Bulgarian energy sector and the trade in electricity in particular, have been a topical and morbid theme for years now. This is in consequence of the disproportions superimposed with time and contradictory rights and obligations of players in the Bulgarian electric energy market. Most generally they boil down to the following:

- In September 2008 the Bulgarian government decided to amalgamate the energy companies of Bulgaria into Bulgarian Energy Holding (BEH), which includes NEK, Kozloduy NPP, Maritsa - East 2 TPP, Maritsa-East Mines, Bulgargaz, Bulgartransgaz and Bulgartel;

- The development of the electric energy market over the period 2004-2014 is schematically presented in the following table (2014 data are estimations):

Table 1

\begin{tabular}{|l|c|c|c|c|c|c|c|c|c|c|c|}
\hline \multicolumn{1}{|c|}{ Year } & 2004 & 2005 & 2006 & 2007 & 2008 & 2009 & 2010 & 2011 & 2012 & 2013 & 2014 \\
\hline Electric Energy Producers & 4 & 6 & 6 & 7 & 7 & 7 & 6 & 7 & 7 & 9 & 9 \\
\hline Wholesale Consumers & 7 & 14 & 31 & 62 & 57 & 61 & 65 & 77 & 105 & 2096 & 2100 \\
\hline Wholesale Traders & 0 & 2 & 10 & 24 & 20 & 26 & 35 & 46 & 47 & 52 & 55 \\
\hline
\end{tabular}


Annual generation of electricity over the period varies between 45 and 50 terawatt-hours (TWh) which is indicative of fluctuations in the yearly consumption under $10 \%$ against the previous year.

The increasing number of wholesale consumers and traders purchasing and selling electric energy on the Bulgarian market is a sure sign of the improved market environment and the increased opportunities for competition. Yet I need to immediately note that the 'free market' occupies a mere $9.2 \%$ of the trade in electric energy for 2013 [8, p. 23], while the expectations for 2014 are that the quantities of electric energy sold on the free market will be some $10 \%$ of the total quantity for the year.

- $\quad$ Electric energy consumption is irregular during the different hours of the day and this forces the System Operator of the respective territory to temporarily disconnect particular producers (the time of forced outage of capacity varies from several hours for HPP and TPP to 2-3 days for NPP, with at least the same time needed to put them back into generation mode), or to connect new capacities to the system as it must be balanced all the time - to have just as much electric energy generated as will be consumed. The classical example of balancing the electric energy system are hydropower plants which generate electricity in peak hours and then become consumers and start pumping the water back upwards so that it can be used again in the generation of electric energy. (See Art. 108.(1) of the Energy Law (EL): 'Single operational planning, coordination and control of the electric energy system is performed by the operator of the electric transmission network and by the operators of each of the electricity distribution networks.)

- The main regulatory body is the State Energy and Water Regulatory Commission (SEWRC). A total 13 principles are set forth in Art. 23 of EL by which the Commission shall be guided in performing its regulatory powers. Such principles are in full compliance with the requirements of European Directive 2009/72/EC, yet their application is usually accompanied by contradictory comments and opinions of various experts from the sector.

- Contracts concluded for long-term purchase of energy with Contour Global Maritsa East 3 and AES 3C Maritsa East 1 EOOD from 2001 make the provision that they will sell all their production to NEK at a price guaranteeing the return of their investment for a period of 10 years. It is noted in the SEWRC report that the total costs for 'non-generated energy' that are paid to the two power plants amount to 274 mill. Levs for 2013 because there was no consumption in Bulgaria and the price of the generated electric energy is significantly higher and can not be sold in neighbouring markets. [7, 16]

- The main large consumers of electric energy, i.e. those selling to the end consumers - the three power distribution enterprises - EVN, CEZ and Energo-Pro are purchasing all the electric energy they need at a fixed price which shall guarantee a profit of $8 \%$ to them, in accordance with the regulations of SEWRC and the signed privatization contracts;

- The differences in prices of individual producers also are specified by SEWRC and they are speaking in their own way when exemplifying the disproportions laid down in time:

\begin{tabular}{|l|c|}
\hline Prices of energy and availability of producers of electric energy for the regulated market & price in Levs per MWh \\
\hline Kozloduy NPP & 30 \\
\hline Maritsa East 1 TPP & 90.35 \\
\hline Maritsa East 2 TPP & 68.30 \\
\hline Maritsa East 3 TPP & 70.88 \\
\hline Factory power plants & 128.65 \\
\hline District heating plants & 183.46 \\
\hline Renewable sources of energy & 299.05 \\
\hline Hydro-power plants property of national electric company & 63.64 \\
\hline Approved price for the national electric company as 'public supplier' & 110.58 \\
\hline
\end{tabular}

The price of electric energy from the thermal power plants in Maritsa East is two to three times higher that that from NPP and this is mainly due to the commitment assumed for purchasing the entire quantity of electric energy produced by the two TPPs;

- The National Electric Company (NEK) has the obligation of a 'public supplier' by virtue of Art. 93a of EL. 'The Public supplier shall purchase electric energy from producers connected to the transmission grid under contracts of long-term purchase of availability and electric energy, as well as energy generated from renewable sources, from highly efficient combined production ....' Most generally, public expectations are placed on the National Electric Company to deliver electric energy to all end consumers and to maintain 'fair' prices. In order to meet such expectations NEK purchases the cheap electric energy generated by Kozloduy 
NPP, covers the costs of availability and buys out the entire quantity of electric energy produced from renewable energy sources (RES). The price of the public supplier is thus obtained - 110.58 Levs for one Mega Watt hour (1 MWh) as shown in the drawing. It was increased from 01.07.2014 to 114.10 Levs per MWh, net of VAT, by SEWRC Decision No. Ц - 12 of 30.06.2014.

- Another problem is the high price of electric energy from renewable energy sources, it being exactly 10 times higher compared against that of NPP Kozloduy. The addition included to the price for end consumers for renewable energy sources in Germany is in the amount of 5.3 Eurocents per kWh. [11, p. 19]

- Control in the energy sector is vested in the Ministry of Economy, Energy and Tourism - MEET. (Art. 75. (1) The Minister for economy, energy and tourism shall exercise preliminary, ongoing and subsequent control ...'). The embedded extensive disproportions however, and probably other lesser contradictions make the SEWRC, MEET and NEK implement new, higher and even more difficult to understand fees - for transmission, additions for green energy, fee for non-recoverable investment costs, 'Public' fee, etc. Any one having the opportunity of making use of the non-recoverable investment costs fee can spend a lot of money for nothing, because consumers of his service will pay all this again to the last cent. What other better opportunity there can exist for uncontrolled spending? It is nether motivated nor explained why each end consumer must pay for each Mega Watt of electric energy 16.80 Levs to NEK in 'Public' fee. What is being compensated with this and how? Other disproportions are created by the increase in transmission fees - 'Until 31.07.2013 this model made provision for the obligations to the public to be included in the price for transmission. Over the past few years a lasting trend was marked towards increase in such costs and their level in the period 2012-2013 resulted in an exceptional increase in the total sum payable to the price of transmission, which actually blocked Bulgarian export of electric energy.' [4, p. 30]

- By its Decision No. Л-422 dated 31.03.2014 SEWRC granted a license for the activity 'organization of a stock market of electric energy' for a term of 10 years to the state company - part of the Bulgarian Energy Holding $(\mathrm{BEH})$ - Bulgarian Independent Energy Exchange EAD. This company will use the technical and material resources of Electricity System Operator EAD and for such purpose the system operator undertakes to separate, rehabilitate and provide the module Organized Market 'Day forward', which has been part of the electric energy market in Bulgaria since 2010 until now. A Business Plan of Bulgarian Independent Energy Exchange EAD was presented for the period 2914-2018, wherein provision is made for starting the activity in 2014 and expansion in 2016 by purchasing a platform for 'market coupling' through which it will be possible to organize a stock market within the framework of the same day. It is envisaged to sell in 2014 on the stock market quantities a little over 4 Terra Watt hours and in 2018 such quantity is expected to double - to 8.5 Terra Watt hours. Provision is made for a fee for transactions on this exchange in the amount of 0.10 Levs per Mega Watt hour (MWh). One can notice that the presented Business Plan is for 4 years and the License was granted for 10 years. There was interest also expressed by the private company 'Bulgarian Energy Exchange' which applied for the issuance of this license too, but it was not approved.

The process of transformation from state monopoly in the energy sector to a free efficient market is accomplished when participants in this dealing begin to make transaction among them at transparent exchange rules and guaranteed equal treatment of all players in the market. This market shall also imply the striking of term deals (futures and options) under perfect regulation because the interest of each participant in the trade in electric energy can be protected with the appropriate selection of term deals against risks unacceptable therefor.

There is a text in the Annual Report of SEWRC for the European Commission that '...the income available to Bulgarian households is the lowest compared to the other EU countries. Although the price of electric energy for the households is also the lowest, the share of population's income used to pay electric energy bills is considerably higher than the average one for the EU.

In order to discontinue this Bulgarian paradox to pay the lowest price for electric energy in Europe and at the very same time such price to be the greatest burden for Bulgarian households we must join, as soon as possible, the European Energy Exchange and to see generated electricity sold in a transparent manner. NEK obligations as a public supplier and the agreed rights of other players in the trade in the Bulgarian market shall be regulated and compensated by the government beyond any market relations. Most probably this again will be tax and non-tax burdens in the price for end consumers yet the state must intervene on its part in shouldering the burdens in our energy system as all this had happened with the collaboration or inaction of the ruling government structures.

Moreover, as of January 2015 there are monthly, quarterly and yearly futures sold in the European Energy Exchange for electric energy with base load for the market of Greece and for the market in Rumania. 
Should Bulgaria decide to join the European Energy Exchange this will be a definite sign that new disproportions will not accumulate and bills of consumers will become transparent and predictable. Otherwise the territory of Bulgaria will remain an isolated and non-transparent electric energy market with bad consequences for all of us.

In conclusion I must note that the European Energy Exchange EEX indeed provides a perfect market mechanism of determining the exchange prices of primary energy sources in Europe and for electric energy, in particular. It is also evident that Bulgaria's territory is the only one still remaining outside the market of the European Energy Exchange and this does not deserve any high esteem, as far as I am concerned.

\section{References}

Directive 2009/72/EC Of The European Parliament And The Council dated 13 July 2009 concerning the common rules for the internal market in electric energy concerning the common rules for the internal market in electric energy and repealing Directive 2003/54/EC

The Energy Act

RULES of trade in electric energy - issued by the State Energy and Water Regulation Commission, promulgated SG, issue 66 dated 26.07.2013, effective from 26.07.2013, am. \& supp, issue 39 dated 9.05.2014.

Annual Report of SEWRC for the European Commission, July 2014, p. 65.

SEWRC decisions №№: ТЕ-023/29.05.2014; Л - 422/31.03.2014; EЕ - 1/27.05.2014; И1 -Л-408/29.01.2014; ПАМ - 1/24.01.2014; И2Л-147/06.01.2014.

Arguments to Decision № Ц-43/30.12.2013 by SEWRC

Price of electric energy on the regulated market during the new price period 1.07.2014-30.06.2015.

Annual Financial Statement of Electricity System Operator EAD for the years 2007, 2008, 2009, 2011, 2012.

Annual Report of NEK for 2011, 2012, 2013, p. 56.

Hull, J. Optionen, Futures und andere Derivate, 7., aktualisierte Aufgabe, Pearson Studium, 2009, p. 713

EPEXSPOT Anual Report 2013, p. 43

EEX Zulassungsordnung Dokument Version 005a 16.12.1013 Ort Leipzig, p. 15.

EEX-Börsenordnung der EEX, Leipzig, $36 \mathrm{~s}$.

Bedingungen für den Handel an der EEX, Leipzig, Dokumentenversion 0035a, p. 30.

Bedingungen für den Handel an der EEX Datum 01.01.2015 Ort Leipzig Dokumentenversion 0039a, p. 25.

EEX-Kontraktspezifikation, Dokumentversion / Document Release 18.12.2013, Leipzig 0037b, p. 130. 